\title{
PENGAWASAN PREVENTIF TERHADAP PERATURAN DAERAH YANG BERCIRI KHAS DAERAH
}

\author{
Victor Juzuf Sedubun \\ Fakultas Hukum Universitas Pattimura Ambon \\ E-mail : v.j.sedubun@gmail.com
}

\begin{abstract}
ABSTRAK
Wewenang pembentukan Peraturan Daerah yang berciri khas daerah diatur dalam Pasal 18B UUD NRI Tahun 1945, Pasal 136 ayat (3) UU Nomor 32 Tahun 2004, Pasal 14 UU Nomor 12 Tahun 2011, Pasal 236 ayat (4) UU Nomor 23 Tahun 2014. Parameter pengawasan Peraturan Daerah, yaitu: bertentangan dengan peraturan perundang-undangan yang lebih tinggi, bertentangan dengan kepentingan umum dan kesusilaan. Parameter pengawasan oleh Mahkamah Agung, yaitu: bertentangan dengan peraturan perundang-undangan yang lebih tinggi, dan pembentukan peraturan daerah tidak memenuhi ketentuan yang berlaku. UU Nomor 23 Tahun 2014 perlu mengatur tentang model pengawasan terhadap Peraturan Daerah yang berciri khas daerah adalah pengawasan preventif dengan parameter: a) bertentangan dengan UUD NRI Tahun 1945 dan undangundang; dan b) bertentangan dengan nilai-nilai budaya masyarakat di daerah.
\end{abstract}

Kata kunci: Pengawasan Preventif, Peraturan Daerah yang Berciri Khas Daerah

\section{ABSTRACT}

Authority to establish the Local Regulation that based on the characteristic of the region is regulated under Article $18 B$ of the Constitution of the Republic of Indonesia of 1945, Article 136 paragraph. 3 of Act No. 32 of 2004, Article 14 of Law No. 12 of 2011 and Article 236 paragraph 4 of Law No. 23 of 2014. Control parameter Local Regulation by the Government, which is contrary to the laws and regulations are higher, the Local Regulation may be annulled if it is contrary to the public interest and morals. The control parameter by the Supreme Court are: contrary to the laws and higher regulations, and the establishment of local regulations do not meet the applicable provisions. Law No. 23 of 2014 to regulate specifically on preventive supervision of the Local Regulation that based on characteristic of the region, with parameters: a. Contrary to the Constitution of the Republic of Indonesia Year 1945 of 1945 and the laws; and b. contrary to the cultural values of the people in the area.

Keywords: Preventive Supervision, Local Regulation that based on characteristic of the region.

\section{Pendahuluan}

Ketentuan Pasal 1 ayat (1) Undang-Undang Dasar Negara Republik Indonesia Tahun 1945 (selanjutnya

dalam penulisan ini disingkat UUD NRI Tahun 1945) menyatakan bahwa: "Negara Indonesia adalah negara kesatuan yang berbentuk 
republik". Pengaturan Pasal 1 ayat (1) UUD NRI Tahun 1945 sangat penting mengingat kondisi geografis negara Indonesia yang terdiri dari banyak pulau.

Ernest Utrecht juga mengemukakan pendapatnya tentang negara kesatuan dengan melihat hubungan dengan negara kesatuan yang tidak terdiri atas beberapa daerah yang berstatus negara bagian. Menurut Ernest Utrecht (1983), “... suatu negara kesatuan ialah suatu negara yang tidak terdiri dari beberapa daerah yang berstatus negara bagian (deelstaat) dengan undang-undang dasar sendiri, biasanya juga dengan kepala negara sendiri dan materi-materi sendirisendiri, serta merdeka dan berdaulat."

Pelimpahan wewenang dalam desentralisasi ketatanegaraan berakibat pada beralihnya kewenangan Pemerintah secara tetap. Pemerintahan kehilangan kewenangan yang telah dilimpahkannya dan beralih kepada pihak yang menerima pelimpahan kewenangan tersebut. Dalam perspektif ketatanegaraan, desentralisasi merupakan pelimpahan kekuasaan pemerintah dari pusat kepada daerahdaerah untuk mengurus rumah tangganya sendiri (daerah-daerah otonom). Desentralisasi adalah juga cara atau sistem untuk mewujudkan asas demokrasi yang memberikan kesempatan kepada rakyat untuk turut serta berpartisipasi dalam proses penyelenggaraan pemerintahan negara.

Pemerintah sebagai pemberi otoritas berkewajiban untuk melakukan pengawasan terhadap kewenangan yang diberikan untuk mencegah terjadinya penyimpangan terhadap penggunaan kewenangan yang dilakukan oleh Pemerintah Daerah. Di sisi lain, Pemerintah Daerah bertanggung jawab untuk melaksanakan kewenangan yang diterima, harus berada dalam ketentuan yang telah diatur, sehingga pelaksanaan kewenangan tersebut mencapai hasil yang diharapkan.

Salah satu wujud penggunaan kewenangan penyelenggaraan pemerintahan oleh Pemerintah Daerah adalah kewenangan untuk membentuk Peraturan Daerah dan peraturan-peraturan lainnya sebagaimana diatur dalam Pasal 18 ayat (6) UUD NRI Tahun 1945. Kewenangan pembentukan Peraturan Daerah selanjutnya dijabarkan dalam Pasal 236 UU Nomor 23 Tahun 2014 menyatakan bahwa:

(1) Untuk menyelenggarakan Otonomi Daerah dan Tugas Pembantuan, Daerah membentuk Peraturan Daerah.

(2) Peraturan Daerah sebagaimana dimaksud pada ayat (1) dibentuk oleh DPRD dengan persetujuan bersama kepala Daerah.

(3) Peraturan Daerah sebagaimana dimaksud pada ayat memuat materi muatan:

a. penyelenggaraan

Otonomi Daerah dan Tugas Pembantuan; dan

b. penjabaran lebih lanjut ketentuan peraturan perundang-undangan yang lebih tinggi.

(4) Selain materi muatan sebagaimana dimaksud pada ayat (3) Peraturan Daerah dapat memuat materi muatan lokal sesuai dengan ketentuan 
peraturan perundang-undangan.

Pasal 18 ayat (1), ayat (2), dan ayat (5) UUD NRI Tahun 1945menegaskan bahwa:

(1) Negara Kesatuan Republik Indonesia dibagi atas daerahdaerah provinsi dan daerah provinsi itu dibagi atas kabupaten dan kota, yang tiap-tiap provinsi, kabupaten, dan kota itu mempunyai pemerintahan daerah, yang diatur dengan undangundang.

(2) Pemerintahan daerah provinsi, daerah kabupaten, dan kota mengatur dan mengurus sendiri urusan pemerintahan menurut asas otonomi dan tugas pembantuan.

(5) Pemerintahan daerah menjalankan otonomi seluas-luasnya, kecuali urusan pemerintahan yang oleh undang-undang ditentukan sebagai urusan Pemerintah Pusat.

Makna Pasal 18 UUD NRI Tahun 1945 adalah Negara Kesatuan Republik Indonesia dibagi dalam daerah-daerah provinsi dan selanjutnya daerah provinsi dibagi lagi atas daerah-daerah kabupaten dan kota. Daerah-daerah provinsi, kabupaten dan kota diserahkan hak untuk mengatur dan mengurus pemerintahannya masingmasing menurut asas otonomi dan tugas pembantuan. Otonomi yang diberikan adalah otonomi yang seluasluasnya, kecuali terhadap urusan yang tidak diserahkan tetap menjadi urusan Pemerintah Pusat (selanjutnya dalam penulisan ini disingkat Pemerintah). Menurut Philipus M. Hadjon (1999), dengan mendasarkan pada ketentuan UUD NRI Tahun 1945, ada dua pola pembagian kekuasaan negara, yaitu secara horisontal dan secara vertikal. Selanjutnya dengan membandingkan pendapat M.C. Burkens, Hadjon menyatakan bahwa pembagian kekuasaan negara secara vertikal adalah pembagian kekuasaan negara antara Pemerintah Pusat dengan Pemerintah Daerah.

Salah satu wujud penggunaan kewenangan penyelenggaraan pemerintahan oleh Pemerintah Daerah adalah kewenangan untuk membentuk Peraturan Daerah. Ketentuan Pasal 18 ayat (6) UUD NRI Tahun 1945 yang menyatakan bahwa: "Pemerintahan daerah berhak menetapkan peraturan daerah dan peraturan-peraturan lain untuk melaksanakan otonomi dan tugas pembantuan."

Kewenangan pembentukan Peraturan Daerah selanjutnya dijabarkan dalam Undang-Undang Nomor 23 Tahun 2014 tentang Pemerintahan Daerah (selanjutnya disingkat UU Nomor 23 Tahun 2014). Ketentuan Pasal 236 UU Nomor 23 Tahun 2014 menyatakan bahwa:

(5) Untuk menyelenggarakan Otonomi Daerah dan Tugas Pembantuan, Daerah membentuk Peraturan Daerah.

(6) Peraturan Daerah sebagaimana dimaksud pada ayat (1) dibentuk oleh DPRD dengan persetujuan bersama kepala Daerah.

(7) Peraturan Daerah sebagaimana dimaksud pada ayat memuat materi muatan:

c. penyelenggaraan Otonomi Daerah dan Tugas Pembantuan; dan

d. penjabaran lebih lanjut ketentuan peraturan 
perundang-undangan yang lebih tinggi.

(8) Selain materi muatan sebagaimana dimaksud pada ayat (3) Peraturan Daerah dapat memuat materi muatan lokal sesuai dengan ketentuan peraturan perundangundangan.

Peraturan Daerah dapat memuat materi muatan lokal sesuai dengan ketentuan peraturan perundangundangan. UU Nomor 32 Tahun 2004 mengunakan nomenklatur "ciri khas" dalam pembentukan Peraturan Daerah, sedangkan Pasal 236 menggunakan nomenklatur "lokal". Pasal 236 tidak menjelaskan lebih lanjut mengenai makna "lokal", sehingga menimbulkan kekaburan terhadap makna lokal, apakah sama dengan makna "ciri khas" dalam UU Nomor 32 Tahun 2004 ataukah berbeda.

Terkait kewenangan ini, maka pembentukan Peraturan Daerah dalam prinsip negara kesatuan mengenal adanya pengawasan terhadap penyelenggaraan pemerintahan di daerah. Pengawasan terhadap penyelenggaraan pemerintahan di daerah, meliputi juga pengawasan terhadap Peraturan Daerah. Konsekuensi dari adanya pembagian kekuasaan, maka kegiatan pengawasan pemerintahan menjadi sesuatu yang wajib dilakukan untuk menjaga keutuhan negara.

Mc Farland (2004 menyatakan bahwa:

"Control is the process by which an executive gets the performance of his subordinates to corespond Closely as possible to chosen plans, orders, objectives or policies"

Pengawasan menurut J.B.J.M. ten Berge (1998) lebih merupakan kegiatan administrasi sejalan dengan kebijakan badan-badan administratif. Seringkali pengawasan tidak mengarah pada pengenaan sanksi, tapi peringatan, konsultasi lebih lanjut dan sejenisnya. Hal ini dapat dilihat dari pendapat J.B.J.M. ten Berge yang menyatakan bahwa:

In de wetgeving en in de literatuur wordt het woord toezicht in meer betekenissen gebruik... Handhavingtoezicht is een bestuurlijke activiteit in het verlengde van het beleid van bestuurorganen. Vaak leidt toezicht ook niet tot het opleggen van een sanctie, maar tot een waarschuwing, nader overleg en dergelijke.

Toezicht omvat in de bewoordingen van een oud arrest de Hoge Raad het 'bewaken, nagaan en gadeslaan van de handelingen of zaken van anderen met het oog op de naleving der verordeningen van de bevoegde macht uitgegaan'. In artikel 132. Eerste lid, Aanwijzingen voor de regelgeving wordt het toezicht omschreven als "de werkzaamheden die door of namens een bestuursorgaan worden verricht om na te gaan of voorschriften worden nageleefd'

(Dalam undang-undang dan literatur kata pengawasan lebih bermakna menggunakan. ... Pengawasan penegakan merupakan kegiatan administrasi sejalan dengan kebijakan badan-badan administratif. Seringkali pengawasan tidak akan mengarah pada pengenaan denda, tapi peringatan, konsultasi lebih lanjut dan sejenisnya.

Pengawasan Mahkamah Agung dalam kata-kata penilaian termasuk "memantau, menyelidiki 
dan mengamati operasi atau urusan orang lain untuk tujuan sesuai dengan peraturan dari otoritas yang berwenang diasumsikan. Pasal 132. Huruf Pertama, untuk pengawasan regulasi didefinisikan sebagai "pekerjaan yang dilakukan oleh atau atas nama suatu badan administratif untuk menentukan apakah aturan dipatuhi).

Paulus Efendi Lotulung (1993) menyatakan bahwa kontrol terhadap suatu peraturan perundang-undangan dapat dilakukan dari beberapa segi, baik dari segi waktu/saat pelaksanaan kontrol, kedudukan badan yang melaksanakan kontrol maupun dari segi sifat kontrol. Dari segi waktu/saat pelaksanaan kontrol atau pengawasan dapat dibedakan dalam 2 (dua) jenis kontrol yaitu (1) controle a-priori, yaitu bilamana pengawasan itu dilakukan sebelum dikeluarkannya suatu keputusan/ketetapan pemerintah dan peraturan lainnya yang pengeluarannya memang menjadi wewenang pemerintah. Dalam hal ini nampak unsur preventif dari maksud kontrol itu, sebab tujuan utamanya adalah untuk mencegah atau menghindari terjadinya kekeliruan; (2) controle $a$ posteriori, yaitu bilamana kontrol atau pengawasan itu baru terjadi setelah dikeluarkannya keputusan/ketetapan pemerintah. Terhadap proses pembentukan Peraturan Daerah, maka bentuk controle a-priori atau yang disebut juga pengawasan preventif dapat diterapkan.

$$
\text { Bagir Manan }
$$

mengemukakan bahwa:

Pengawasan preventif dapat dibedakan atas dua macam, yaitu voortoezicht dan middentoezicht. Voortoezicht, pertimbangan atau pengawasan dijalankan sebelum pemerintah tingkat lebih rendah mengambil atau menetapakan suatu peraturan. Contoh adalah pernyataan tidak keberatan dari pemerintahan tingkat lebih atas. Sedangkan middentoezicht, pengesahan (goedkeuring) atau pengumuman atau pengundangan (afkondiging). Pada tingkat Gemeente, terdapat berbagai macam jenis pengawasan preventif dan yang paling utama adalah pengesahan (goedkeuring).

Pengawasan telah dikenal dalam Undang-Undang Nomor 5 Tahun 1974 tentang Pokok-pokok Pemerintahan di Daerah (disingkat UU Nomor 5 Tahun 1974). UU Nomor 5 Tahun 1974, sebagaimana dikemukakan oleh Philipus $M$. Hadjon (1993), mengenal adanya tiga bentuk pengawasan, yaitu: pengawasan umum, pengaawasan preventif dan pengawasan represif.

Pengawasan Peraturan Daerah dalam UU Nomor 23 Tahun 2014 mengenal adanya dua bentuk pengawasan, yaitu pengawasan preventif dan pengawasan represif. Pengawasan preventif dilakukan terhadap Rancangan Peraturan Daerah, yang dilakukan dalam bentuk evaluasi dan klarifikasi hasil evaluasi; dan pengawasan represif dilakukan terhadap Peraturan Daerah dalam bentuk klarifikasi. Pengawasan Peraturan Daerah dilakukan berdasarkan atas parameter tertentu yang diatur dalam ketentuan beberapa peraturan perundang-undangan, yaitu: bertentangan dengan peraturan perundang-undangan yang lebih tinggi, bertentangan dengan kepentingan umum dan bertentangan dengan kesusilaan. 
Parameter di atas berlaku terhadap semua Peraturan Daerah, termasuk Peraturan Daerah yang materi muatannya berdasarkan pada ciri khas daerah. Pembentukan Peraturan Daerah yang berdasarkan ciri khas daerah dimungkinkan berdasarkan ketentuan Pasal 236 ayat (4) UU Nomor 23 Tahun 2014, yang menyatakan bahwa: "Selain materi muatan sebagaimana dimaksud pada ayat (3) Peraturan Daerah dapat memuat materi muatan lokal sesuai dengan ketentuan peraturan perundang-undangan" (garis bawah oleh penulis).

Ketentuan Pasal 236 ayat (4) UU Nomor 23 Tahun 2014, jika dikaitkan dengan tiga alat uji pengawasan terhadap Peraturan Daerah sebagaimana diatur dalam Pasal 236 ayat (4) UU Nomor 23 Tahun 2014, dapat menimbulkan kendala bagi daerah dalam membentuk Peraturan Daerah. Khususnya Peraturan Daerah yang berciri khas daerah. Untuk itu, permasalahan yang diangkat dalam penulisan ini adalah: apakah model pengawasan yang tepat terhadap Peraturan Daerah yang dibentuk berdasarkan ciri khas daerah?

\section{Metode Penelitian}

$\begin{array}{ccr}\text { Penelitian } & \text { ini } & \text { merupakan } \\ \text { penelitian } & \text { normatif, } & \text { dengan }\end{array}$ menggunakan pendekatan perundangundangan (statute approach) dan pendekatan konseptual (conseptual approach). Bahan hukum primer dan bahan hukum sekunder yang telah dikumpulkan (inventarisasi), kemudian melakukan pengkajian dengan pendekatan perundang-undangan dan pendekatan koseptual. Hasil analisis berupa argumentasi terhadap masalah yang diangkat, sehingga dari argumentasi tersebut, memberikan suatu preskripsi sebagai pemecahan terhadap masalah yang dianalisa.

\section{Hasil Penelitian dan Pembahasan}

Pembentukan hukum tersebut harus didasarkan pada kebenaran fakta yang terjadi dalam masyarakat. Geofferey Samuel (2007) mengemukakan bahwa:

"The object of legal science is the constructed legal model of facts. The idea that the way facts are constructed internally leading to the way that they are thus viewed, is capable of creating a normative dimension quite separate from any normative aspect attaching to a legal rule. This fact construction can be seen as a kind of precategorisation before the facts are formally assigned to an established legal category. How facts are actually constructed at this precategorisation stage might well be an active step in the process of reaching a solution in a case and thus the construction - and reconstruction - of facts is as important as any search for, or an application of, a rule. The facts of a case are not real facts. They are not real-life situations, but are virtual fact because the object of legal science is not the phenomena of the real world (real facts of a case)."

Peran lembaga-lembaga hukum dan konsep merupakan pusat penyelidikan yang dilakukan secara epistemologis dan metodologis hukum. peran lembaga-lembaga hukum dan konsep juga sebagai jembatan 
untuk menghubungkan antara dunia hukum dan fakta sosial. Ada tiga instansi fundamental: orang (persona), hal (res), dan tindakan (actio). Lembaga-lembaga ini bertindak sebagai tiga elemen struktur utama atau titik pelabuhan dalam suatu model dimana hubungan antara unsur-unsur yang memberikan ekspresi dengan sifat struktural dan spasial dari citra faktual.

Peraturan Daerah sebagai produk hukum lokal, memiliki peran yang sama dengan pandangan di atas, yaitu sebagai jembatan penghubungan antara antara dunia hukum dan fakta sosial. Apa yang menjadi cita hukum dalam Peraturan Daerah harus dapat dihubungkan dengan kepentingan dari masyarakat lokal atau masyarakat di daerah.

Hakekat muatan materi Peraturan Daerah yang mengakomodir kepentingan masyarakat di daerah guna mencapai suatu kebahagiaan yang terbesar kepada masyarakat, mesti dihargai oleh penyelenggara pemerintahan di pusat sebagai urusan penyeleggara pemerintahan di daerah dalam mengupayakan kebahagiaan dan kesejahteraan kepada masyarakat di daerah. Pengakuan tersebut pula maka daerah berhak menetapkan Peraturan Daerah untuk menampung kondisi khusus kepada daerah dan mengatur kehidupan bersama masyarakat di daerahnya dalam pergaulan antar individu.

Cita hukum (rechtsidee) mengandung arti bahwa pada hakikatnya hukum sebagai aturan tingkah laku masyarakat berakar pada gagasan, rasa, karsa, cita dan pikiran dari masyarakat itu sendiri. Jadi, cita hukum itu adalah gagasan, karsa, cipta dan pikiran berkenan dengan hukum atau persepsi tentang makna hukum, yang dalam intinya terdiri atas tiga unsur, yaitu: keadilan, kehasilgunaan (doelmatigheid) dan kepastian hokum (Arief Sidharta, 2009)

Menurut Eugen Ehrlich, hukum positif dapat memiliki daya berlaku yang efektif jika diselaraskan dengan hukum yang hidup dalam masyarakat (the living law) dan mereka yang berperan sebagai pihak yang mengembangkan hukum harus memiliki hubungan yang erat dengan nilai-nilai yang dianut dalam masyarakat bersangkutan. Titik pusat perkembangan hukum tidak terletak pada undang-undang, putusan hakim, atau ilmu hukum, melainkan terletak pada masyarakat itu sediri.

Wewenang pembentukan Peraturan Daerah memiliki kaitan dengan sistem pembagian pemerintahan.

Dasar

konstitusionalitas penyelenggaraan pemerintahan daerah diatur dalam ketentuan Pasal 18 ayat (1) UUD NRI Tahun 1945 yang menyatakan bahwa:

"Negara Kesatuan Republik Indonesia dibagi atas daerahdaerah provinsi, dan daerah provinsi itu dibagi atas kabupaten dan kota, yang tiap-tiap provinsi, kabupaten dan kota itu mempunyai pemerintahan daerah, yang diatur dengan undangundang."

Terkait dengan hal di atas, F. Soegeng Istanto mengemukakan kesimpulan sebagai berikut: 
1. Daerah tidaklah bersifat staat;

2. Wilayah Indonesia mula-mula akan dibagi dalam provinsi-provinsi dan provinsi ini kemudian dibagi lagi dalam daerah-daerah lebih kecil;

3. Daerah ini bisa bersifat otonom dan bisa pula bersifat administrasi;

4. Di daerah otonom dibentuk badan perwakilan Daerah sesuai dengan dasar permusyawaratan dalam sistem pemerintahan negara.

Berkaitan dengan pembentukan produk hukum di daerah, kewenangan pembentukan Peraturan Daerah secara atributif merupakan kewenangan pemerintahan daerah. Kewenangan atribusi yang diberikan oleh UUD NRI Tahun 1945, maka kewenangan Pemerintahan Daerah adalah untuk menetapkan Peraturan Daerah dan peraturan-peraturan lain yang bertujuan untuk melaksanakan otonomi dan tugas pembantuan.

$$
\text { Andrew Arden }
$$

berpendapat bahwa:

"Local government does not exist in a vacuum. Its purpose is to provide for the peoples of their areas that which is or may not be provided by others, whether the private sector or indeed other organs of government (central and appointed bodies with central or local governmental functions). Accordingly, local government is an essential part of the organisation of the state as a whole and, as such, is both regulated by, and accountable to, central government, with which and with other bodies its functions co-exist".

Pemerintahan Daerah yang menyediakan bagi rakyat daerahnya sesuai dengan kebutuhan dan kondisi khusus di daerah, sepanjang masih dapat dipertanggungjawabkan oleh Pemerintahan Daerah Pemerintahan
Daerah yang lebih mengetahui dan memahami kebutuhan masyarakat di daerahnya. Dengan demikian, maka seharusnya Pemerintahan Daerah diberikan kewenangan untuk membentuk Peraturan Daerah, bukan sekedar menetapkan Peraturan Daerah.

Berhubungan dengan penyelenggaraan pemerintahan di daerah, tugas pemerintah adalah memberikan pelayanan dan menyediakan bagi rakyat daerahnya apa yang menjadi kebutuhan rakyatnya. Termasuk di dalamnya adalah memberikan perlindungan dan penghormatan terhadap kondisi khusus dan ciri khas yang dimiliki oleh daerah itu, baik berupa perlindungan dan penghormatan terhadap hak-hak tradisional maupun terhadap kearifan lokal masyarkat di daerah.

$$
\text { Pemerintahan daerah }
$$
kabupaten/kota berdasarkan kewenangan yang diatur dalam Pasal 18B UUD NRI Tahun 1945, Pasal 236 ayat (4) UU Nomor 23 Tahun 2014 dan Pasal 14 UU Nomor 12 Tahun 2011, dapat membentuk Peraturan Daerah yang materi muatannya berdasarkan ciri khas daerah. Materi muatan tentang ciri khas daerah dibolehkan sepanjang mengatur hak-hak tradisional dan kearifan lokal daerah sepanjang hak-hak tradisional dan kearifan lokal tersebut tidak bertentangan dengan konstitusi dan prinsip Negara Kesatuan Republik Indonesia.

untuk menyelenggarakan pengaturan sebagai penjabaran lebih lanjut peraturan perundang- 
undangan yang lebih tinggi dengan memperhatikan ciri khas masingmasing Daerah, merupakan penjabaran lebih lanjut peraturan atau kebijakan yang lebih tinggi oleh satuan pemerintahan yang lebih rendah dan mencerminkan karakteristik Peraturan Daerah sebagai delegated legislation. M. P. Jain (2009) menyatakan bahwa definisi dari delegated legislation adalah: "the subsidiary legislation itself made by the administration in pursuance of the power delegated to it by the legislature" dan "the exercise of the power by the agency".

Karakter Peraturan Daerah sebagai delegated legislation sebagaimana dikemukakan A.W. Bradley dan K.D. Ewing, (2003) di atas yang intinya menyatakan bahwa: "delegated legislation is an inevitable feature of modern government for several reasons.

\section{Pressure on Parliament Time}

2. Technicality of Subject Matter

3. The Need for Flexibility

4. State of Emergency."

Konsekuensi dipertegasnya prinsip pemisahan kekuasaan eksekutif, legislatif dan judikatif dalam naskah Perubahan Pertama UUD 1945 maka produk legislatif daerah ini dapat saja bertentangan dengan produk eksekutif di tingkat pusat. Misalnya, apabila suatu materi Peraturan Daerah Provinsi ataupun Peraturan Daerah Kabupaten/Kota yang telah ditetapkan secara sah ternyata bertentangan isinya dengan Peraturan Menteri di tingkat pusat maka pengadilan haruslah menentukan bahwa Peraturan Daerah itulah yang berlaku sepanjang untuk daerahnya. Peraturan Menteri dimaksudkan untuk berlaku umum di seluruh Indonesia.
Materi muatan Peraturan Daerah yang memperhatikan ciri khas Daerah dilakukan agar Peraturan Daerah tetap menjunjung tinggi adat istiadat masyarakat setempat di mana adat istiadat timbul karena adanya kekuatan yang berada di balik hukum yang selalu berupa kekuatan sosial yaitu adalah adat istiadat. Adat istiadat timbul karena kebiasaan masyarakat untuk melaksanakan aktifitas sosialnya, di mana dalam penegakan aktifitas sosial, diperlukan tekanan-tekanan yang lama-kelamaan adat istiadat yang disertai suatu tekanan tersebut akan menjadi aturan yang harus dijalankan oleh pihak yang berwenang sehingga agar Peraturan Daerah menjadi efektif dan mempunyai kekuatan mengikat dalam masyarakat, Peraturan Daerah harus selalu mempertimbangkan adat istiadat masyarakat tempat berlakunya Peraturan Daerah.

Adanya pengakuan dan penghormatan negara terhadap kesatuan-kesatuan masyarakat hukum adat beserta hak-hak tradisionalnya sepanjang masih hidup dan sesuai dengan perkembangan masyarakat dan prinsip Negara Kesatuan Republik Indonesia, menggambarkan bahwa negara yang di dalamnya terdapat Pemerintahan Daerah yang dibentuk oleh negara, mengakui dan menghormati kesatuan masyarakat hukum adat dan hakhak tradisionalnya. Hak-hak tradisional masyarakat hukum adat termasuk pula di dalamnya 
kearifan lokal dari kesatuan masyakat hukum adat itu sendiri.

Terkait dengan wewenang pemerintahan daerah untuk menetapkan Peraturan Daerah sebagaimana diatur dalam ketentuan Pasal 18 ayat (6) UUD NRI Tahun 1945, maka berdasarkan ketentuan Pasal 18B UUD NRI Tahun 1945 yang mengakui dan menghormati kesatuan masyarakat hukum adat dan hak-hak tradisionalnya, memungkinkan dibentuknya Peraturan Daerah yang didasarkan pada ciri khas dan/atau kondisi khusus masing-masing daerah. UUD NRI Tahun 1945 memberikan kesempatan kepada Daerah untuk membentuk Peraturan Daerah yang didasarkan pada ciri khas dan/atau kondisi khusus yang berakar pada kehidupan masyarakat di daerahnya dengan tetap memperhatikan perkembangan dan prinsip Negara Kesatuan Indonesia.

Urusan pemerintahan yang oleh undang-undang ditentukan sebagai urusan Pemerintah yaitu kewenangan di bidang politik luar negeri, pertahanan, keamanan, peradilan, moneter dan fiskal, agama, serta kewenangan di bidang lain yang diatur dengan undang-undang dengan memperhatikan kekhususan dan keragaman yang dimiliki daerah. Hanya saja perlu dicatat bahwa dalam naskah Perubahan UUD 1945 digunakan perkataan: 'memberikan otonomi yang luas kepada daerah-daerah'. Artinya, kekuasaan asal atau sisa (residual power) tetap berada di Pemerintah Pusat, bukan di daerah; Dalam negara kesatuan (unitary state) kekuasaan asli itu memang berada di Pemerintah, bukan di daerah. Daerah tidak diberikan kekuasaan asli (power) tanpa atribut tetapi kekuasaan yang sudah dilegalisasikan yang biasa disebut kewenangan (authority).

Urusan pemerintahan yang tidak habis dibagi antara Pemerintah, Pemerintah Provinsi dan Pemerintah Kabupaten/Kota menjadi urusan sisa yang kewenangan pemerintah pada masing-masing tingkatan. Penggunaan kewenangan terhadap urusan sisa harus ditentukan oleh Pemerintah dengan menggunakan kriteria eksternalitas, akuntabilitas dan efisiensi dengan memperhatikan keserasian hubungan antara Pemerintah, Pemerintah Provinsi dan Pemerintah Kabupaten/Kota.

Pemerintah Provinsi dan Pemerintah Kabupaten/Kota yang akan menyelenggarakan urusan sisa harus mengajukan usulan kepada Pemerintah melalui Mendagri untuk mendapat penetapan tentang bidang-bidang yang menjadi kewenangannya. Penetapan kewenangan penyelenggaraan urusan sisa oleh Mendagri merupakan bentuk pengawasan preventif yang dilakukan oleh Pemerintah terhadap Pemerintah Daerah.

Materi muatan Peraturan Daerah yang berciri khas daerah tidak dicantumkan dalam rincian pembagian urusan pemerintahan antara Pemerintah, Pemerintah Provinsi dan Pemerintah Kabupaten/Kota sebagaimana terdapat dalam lampiran Peraturan Pemerintah Nomor 38 Tahun 2007 tentang Pembagian Urusan Pemerintahan Antara Pemerintah, Pemerintah Provinsi dan 
Pemerintah Kabupaten/Kota. Untuk itu, maka Pemerintah Daerah dapat mengusulkan kewenangan pembentukan Peraturan Daerah yang berciri khas daerah kepada Pemerintah untuk mendapat penetapan.

Pembentukan Peraturan Daerah dalam konteks otonomi daerah harus dapat memperhatikan kebutuhan dan kepetingan daerah. Dengan memperhatikan kebutuhan dan kepentingan daerah, membuka kemungkinan adanya penyimpangan terhadap wewenang yang diberikan karena alasan kebutuhan dan

\section{Perbandingan Wewenang Pengawasan Peraturan Daerah}

\begin{tabular}{|c|c|}
\hline $\begin{array}{l}\text { UUD NRI } \\
\text { Thn } 1945\end{array}$ & $\begin{array}{l}\text { Pasal 24A ayat (1) } \\
\text { Mahkamah Agung berwenang mengadili pada tingkat kasasi, } \\
\text { menguji peraturan perundang-undangan di bawah undang-undang } \\
\text { terhadap undang-undang, dan mempunyai wewenang lainnya yang } \\
\text { diberikan oleh undang-undang. }\end{array}$ \\
\hline $\begin{array}{l}\text { UU No. } 4 \\
\text { Thn } 2004\end{array}$ & $\begin{array}{l}\text { Pasal } 31 \\
\text { (1) Mahkamah Agung mempunyai wewenang menguji peraturan } \\
\text { perundang-undangan di bawah undang-undang terhadap } \\
\text { undang-undang. } \\
\text { (2) Mahkamah Agung menyatakan tidak sah peraturan perundang- } \\
\text { undangan di bawah undang-undang atas alasan bertentangan } \\
\text { dengan peraturan perundang-undangan yang lebih tinggi atau } \\
\text { pembentukannya tidak memenuhi ketentuan yang berlaku. }\end{array}$ \\
\hline $\begin{array}{l}\text { UU No. } 5 \\
\text { Thn } 2005\end{array}$ & $\begin{array}{l}\text { Pasal } 11 \text { ayat (2) } \\
\text { Mahkamah Agung mempunyai kewenangan: } \\
\text { a. mengadili pada tingkat kasasi terhadap putusan yang diberikan } \\
\text { pada tingkat terakhir oleh pengadilan di semua lingkungan } \\
\text { peradilan yang berada di bawah Mahkamah Agung; } \\
\text { b. menguji peraturan perundang-undangan di bawah undang- } \\
\text { undang terhadap undang-undang; }\end{array}$ \\
\hline $\begin{array}{l}\text { UU No. } 32 \\
\text { Thn } 2004\end{array}$ & $\begin{array}{l}\text { Pasal } 145 \\
\text { (1) Perda disampaikan kepada Pemerintah paling lama } 7 \text { (tujuh) } \\
\text { hari setelah ditetapkan. } \\
\text { (2) Perda sebagaimana dimaksud pada ayat (1) yang } \\
\text { bertentangan dengan kepentingan umum dan/atau peraturan } \\
\text { perundang-undangan yang lebih tinggi dapat dibatalkan oleh } \\
\text { Pemerintah. }\end{array}$ \\
\hline
\end{tabular}

kepentingan daerah. Untuk itu, pengawasan dibutuhkan guna memastikan jalannya tidak terjadi penyimpangan terhadap kewenangan yang diberikan. Wewenang pengawasan Peraturan Daerah dalam UUD NRI Tahun 1945, UU Nomor 4 Tahun 2004, UU Nomor 5 Tahun 2005, UU Nomor 32 Tahun 2004, UU Nomor 23 Tahun 2014, PP Nomor 79 Tahun 2005 dan Permendagri Nomor 1 Tahun 2014 dapat dilihat pada tabel di bawah ini : 
(4) Apabila Menteri Dalam Negeri menyatakan hasil evaluasi rancangan Perda tentang APBD dan rancangan Peraturan Gubernur tentang penjabaran APBD bertentangan dengan kepentingan umum dan peraturan perundang-undangan yang lebih tinggi, Gubernur bersarna DPRD melakukan penyempurnaan paling lama 7 (tujuh) hari terhitung sejak diterimanya hasil evaluasi.

(5) Apabila hasil evaluasi tidak ditindaklanjuti oleh Gubernur dan DPRD, dan Gubernur tetap menetapkan rancangan Perda tentang APBD dan rancangan Peraturan Gubernur tentang penjabaran APBD menjadi Perda dan Peraturan Gubernur, Menteri Dalam Negeri rnembatalkan Perda dan Peraturan Gubernur dimaksud sekaligus menyatakan berlakunya pagu APBD tahun sebelumnya.

Pasal 186

(4) Apabila Gubernur menyatakan hasil evaluasi rancangan Perda tentang APBD dan rancangan Peraturan Bupati/Walikota tentang Penjabaran APBD tidak sesuai dengan kepentingan umum dan peraturan perundang-undangan yang lebih tinggi, Bupati/Walikota bersama DPRD melakukan penyempurnaan paling lama 7 (tujuh) hari sejak diterimanya hasil evaluasi.

(5) Apabila hasil evaluasi tidak ditindaklanjuti oleh Bupati/Walikota dan DPRD, dan Bupati/Walikota tetap menetapkan rancangan Perda tentang APBD dan rancangan Peraturan Bupati/Walikota tentang penjabaran APBD menjadi Perda dan Peraturan Bupati/Walikota, Gubernur membatalkan Perda dan Peraturan Bupati/Walikota dimaksud sekaligus menyatakan berlakunya pagu APBD tahun sebelumnya.

UU No. 23 Pasal 251

Thn 2014 (1) Peraturan Daerah Provinsi dan peraturan gubernur yang bertentangan dengan ketentuan peraturan perundangundangan yang lebih tinggi, kepentingan umum, dan/atau kesusilaan dibatalkan oleh Menteri.

(2) Peraturan Daerah Kabupaten/Kota dan peraturan bupati/wali kota yang bertentangan dengan ketentuan peraturan perundang-undangan yang lebih tinggi, kepentingan umum, dan/atau kesusilaan dibatalkan oleh gubernur sebagai wakil Pemerintah Pusat.

\section{PP No. 79 Pasal 37}

Thn 2005 (1) Peraturan Daerah dan Peraturan Kepala Daerah disampaikan kepada Pemerintah paling lama 7 (tujuh) hari sejak ditetapkan.

(2) Pemerintah melakukan pengawasan terhadap Peraturan Daerah dan Peraturan Kepala Daerah. 


\begin{tabular}{|c|c|}
\hline & $\begin{array}{l}\text { Pasal } 40 \\
\text { (2) Apabila Gubernur tidak menindaklanjuti sebagaimana pada } \\
\text { ayat (1) dan tetap menetapkan menjadi peraturan daerah } \\
\text { dan/atau peraturan kepala daerah, Menteri dapat membatalkan } \\
\text { peraturan daerah dan peraturan kepala daerah tersebut dengan } \\
\text { peraturan Menteri. } \\
\text { (3) Apabila Bupati/Walikota tidak menindaklanjuti sebagaimana } \\
\text { pada ayat (1) dan tetap menetapkan menjadi peraturan daerah } \\
\text { dan/atau peraturan kepala daerah, Gubernur dapat } \\
\text { membatalkan peraturan daerah dan peraturan kepala daerah } \\
\text { tersebut dengan peraturan Gubernur. }\end{array}$ \\
\hline $\begin{array}{l}\text { Permen- } \\
\text { dagri No. } \\
1 \text { Thn } \\
2014\end{array}$ & $\begin{array}{l}\text { Pasal } 88 \\
\text { (1) Gubernur menyampaikan Peraturan Daerah provinsi dan } \\
\text { peraturan gubernur kepada Menteri Dalam Negeri melalui } \\
\text { Sekretaris Jenderal paling lama } 7 \text { (tujuh) hari setelah } \\
\text { ditetapkan untuk mendapatkan klarifikasi. } \\
\text { (2) Bupati/walikota menyampaikan Peraturan } \\
\text { kabupaten/kota dan peraturan bupati/walikota kerah } \\
\text { gubernur dan kepada Menteri Dalam Negeri melalui Sekretaris } \\
\text { Jenderal paling lama } 7 \text { (tujuh) hari setelah ditetapkan untuk } \\
\text { mendapatkan klarifikasi. } \\
\text { (3) Bupati/walikota menyampaikan Peraturan } \\
\text { kabupaten/kota dan peraturan bupati/walikota kepada } \\
\text { gubernur dan kepada Menteri Dalam Negeri melalui Sekretaris } \\
\text { Jenderal paling lama } 7 \text { (tujuh) hari setelah ditetapkan untuk } \\
\text { mendapatkan klarifikasi. }\end{array}$ \\
\hline
\end{tabular}

Pengawasan Peraturan Daerah yang diatur dalam UU Nomor 32 Tahun 2004, UU Nomor 23 Tahun 2014, PP Nomor 79 Tahun 2005 dan Permendagri Nomor 1 Tahun 2014 tidak mengatur secara tegas tentang pengawasan terhadap Peraturan Daerah yang berciri khas dan/atau kondisi khusus daerah. Pengawasan terhadap Peraturan Daerah yang diatur dalam UU Nomor 32 Tahun 2004, UU Nomor 23 Tahun 2014, PP Nomor 79 Tahun 2005 dan Permendagri Nomor 1 Tahun 2014 hanya mengatur tentang pengawasan preventif dalam bentuk

evaluasi dan klarifikasi hasil
evaluasi dan pengawasan represif dalam bentuk klarifikasi dan pembatalan terhadap Peraturan Daerah yang bersifat umum, tidak terdapat pengaturan pengawasan terhadap Peraturan Daerah yang dibentuk berdasarkan ciri khas dan/atau kondisi khusus daerah.

Prosedur pembatalan Peraturan Daerah digambarkan pada Bagan 1 dan Bagan 2 di bawah ini: 


\section{Bagan 1}

\section{Pembatalan Peraturan Daerah menurut Pasal 145 Undang-Undang} Nomor 32 Tahun 2004






\section{Bagan 2 \\ Pembatalan Peraturan Daerah menurut Pasal 251 Undang-Undang Nomor 23 Tahun 2014}

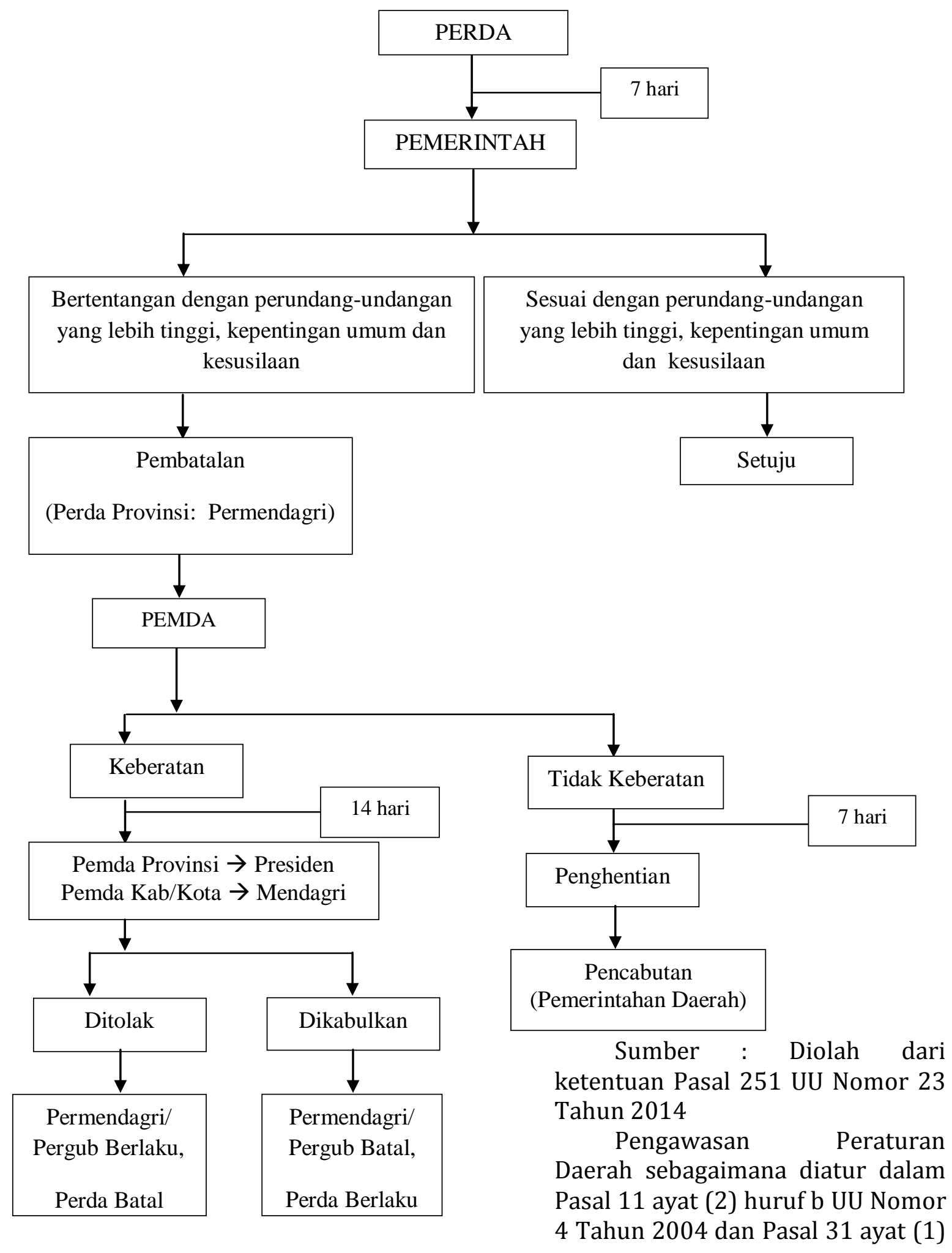


dan ayat (2) UU Nomor 5 Tahun 2004 merupakan penjabaran dari ketentuan Pasal 24A ayat (1) UUD NRI Tahun 1945 memberikan kewenangan kepada Mahkamah Agung untuk melakukan pengawasan terhadap Peraturan Daerah. Namun tidak menyatakan secara jelas, apakah pengawasan yang dilakukan oleh Mahkamah Agung terhadap Peraturan Daerah termasuk di dalamnya Peraturan Daerah yang dibentuk berdasarkan ciri khas daerah ataukah tidak.

Kewenangan pengawasan oleh Presiden sebagai pemegang kekuasaan pemerintahan dalam negara Indonesia, selanjutnya ditetapkan dalam UU Nomor 32 Tahun 2004 sebagaimana telah diganti dengan UU Nomor 23 Tahun 2014 sebagai penjabaran dari kekuasaan pemerintahan dalam bentuk pengawasan dan pembinaan terhadap Pemerintahan Daerah. Pemerintah dalam melakukan pengawasan sebagaimana dimaksud dalam Pasal 251 UU Nomor 23 Tahun 2014, bersikap aktif dalam mengawasi setiap Peraturan Daerah, tanpa menuggu adanya laporan dari pihak lainnya, seperti masyarakat (perseorangan), LSM, badan hukum publik dan badan hukum privat maupun organ pemerintahan lainnya.

\section{Simpulan}

Pasal 18B UUD NRI Tahun 1945 merupakan dasar konstitusional wewenang Pemerintahan Daerah membentuk Peraturan Daerah yang berciri khas daerah. Pembentukan Peraturan Daerah harus mengakomodir pandangan hidup, nilai-nilai budaya, dan keadilan. Peraturan Daerah yang berciri khas daerah harus menjadi sarana untuk menciptakan dan memelihara ketertiban, stabilitas, prediktabilitas, sarana pelestarian nilai-nilai budaya, pendidikan, pengadaban masyarakat, dan pembaruan masyarakat.

Pasal 136 ayat (3) UU Nomor 32 Tahun 2004, juncto Pasal 14 UU Nomor 12 Tahun 2011 juncto Pasal 236 ayat (4) UU Nomor 23 Tahun 2014 menjamin adanya pembentukan Peraturan Daerah yang berciri khas daerah dan menjadi cantolan bagi Pemerintahan Daerah untuk membentuk Peraturan Daerah yang didasarkan pada ciri khas daerah dengan memperhatikan prinsipprinsip NKRI. Perubahan kata "ciri khas" dalam UU Nomor 32 Tahun 2004 menjadi kata "lokal" dalam UU Nomor 23 Tahun 2014, nomenklatur "materi muatan lokal" memiliki makna yang lebih luas dibandingkan dengan kata "ciri khas" dan "kondisi khusus". Sesuatu yang bersifat lokal terkandung di dalamnya kekhasan dan kekhususan yang dimiliki oleh suatu daerah.

Materi muatan Peraturan Daerah yang berciri khas daerah tidak dicantumkan dalam rincian pembagian urusan pemerintahan antara pemerintah, pemerintah provinsi dan pemerintah kabupaten/kota. Untuk itu, maka Pemerintah Daerah dapat mengusulkan kewenangan pembentukan Peraturan Daerah yang berciri khas daerah kepada Pemerintah untuk mendapat penetapan. Penetapan penggunaan urusan sisa sebagai materi muatan Peraturan Daerah yang berciri khas 
daerah merupakan bentuk pengawasan preventif.

UU Nomor 23 Tahun 2014 sebagai hukum positif yang mengatur tentang Pemerintahan Daerah perlu mengatur secara khusus tentang pengawasan terhadap Peraturan Daerah yang berciri khas daerah. Pengaturan yang ditambahkan, khususnya mengenai parameter proses pembentukan dan pengawasan Peraturan Daerah yang Berciri Khas Daerah. Paramaeter pengawasan Peraturan Daerah yang Berciri Khas Daerah oleh Pemerintah adalah:

a. bertentangan dengan UUD NRI Tahun 1945 dan undang-undang.

b. bertentangan dengan nilai-nilai budaya masyarakat di daerah.

\section{Daftar Pustaka}

Arden, Andrew, 2008, Local Government Constitutional Law and Administrative Law, Thompson Sweet\&Maxwell, London.

Berge, J.B.J.M. ten, 1998, Besturen Door De Overheid, Nederlands Algemeen Bestuursrecht I, W.E.J. Tjeenk Willink, Deventer.

Bradley, A. W. and K. D. Ewing, 2003, Constitutional and Administrative Law. $13^{\text {th }}$ edition. Pearson Education Limited, Essex.

Darmodiharjo, Darji dan Shidarta, 2005, Pokok Pokok-Pokok Filsafat Hukum, Apa dan Bagaimana Filsafat Hukum Indonesia, Gramedia Pustaka Utama, Jakarta.

Farland, D .E. Mc, 2004, Management Principles and Practice, Mac Milan, New York.

Hadjon, Philipus M., 1993, Pengantar Hukum Administrasi Indonesia,
Gadjah Mada University Press, Yogyakarta.

1999, Sistem

Pembagian Kekuasaan Negara

(Analisis Hukum Tata Negara). Juridika. Vol. 14. Nomor $6 . \quad$ NovemberDesember 1999, Fakultas Hukum Universitas Airlangga, Surabaya.

Istanto, F. Soegeng, 1968, Beberapa Segi Hubungan Pemerintah Pusat dan Daerah Dalam Negara Kesatuan Indonesia, Fakultas Sosial dan Politik UGM, Yogyakarta.

Lotulung, Paulus Effendi, 1993, Beberapa Sistem Tentang Kontrol Segi Hukum Terhadap Pemerintah, Citra Aditya Bakti, Bandung.

Manan, Bagir, 2004, Hubungan Antara Pusat dan Daerah Menurut UUD 1945, Pustaka Sinar Harapan, Jakarta.

Samuel, Geofferey, 2007, Epistimology and Method in Law, Kent Law School, UK, Juridishe Bibliotheek University Utrecht.

Sidharta, Bernard Arief, 2009, Refleksi Tentang Struktur Ilmu Hukum, Mandar Maju, Bandung.

Sukardi, 2009, Pembatalan Peraturan Daerah dan Akibat Hukumnya, Disertasi, Program Pascasarjana Universitas Airlangga, Surabaya.

Utrecht, Ernst, 1983, Pengantar Dalam Hukum Indonesia, Ichtiar Baru bekerja sama dengan Sinar Harapan, Jakarta 